\title{
Induction by Glucocorticoids of Angiotensin Converting Enzyme Production from Bovine Endothelial Cells in Culture and Rat Lung In Vivo
}

\author{
F. A. O. Mendelsohn, C. J. Lloyd, C. KaChel, and J. W. Funder, University of \\ Melbourne, Department of Medicine, Austin Hospital, Heidelberg, Victoria, \\ 3084; Medical Research Centre, Prince Henry's Hospital, Melbourne, \\ Victoria, 3004, Australia
}

\begin{abstract}
A B S T R A C T The effect of corticosteroids on angiotensin converting enzyme was investigated in endothelial cell cultures and intact rat lung. Cultured endothelial cells from bovine aorta showed net production of angiotensin converting enzyme (ACE) over 2 $d$ culture in serum-free medium. Dexamethasone (DM) increased cell ACE activity six- to sevenfold at $100 \mathrm{nM}$ with a threshold effect at $0.3 \mathrm{nM}$. The effect of DM on ACE production was completely inhibited by actinomycin $\mathrm{D}$ or cycloheximide. Deoxycorticosterone (DOC) and aldosterone were markedly less active, with a threshold near $100 \mathrm{nM}$ and significant (two to threefold) stimulation of ACE activity at $1 \mu \mathrm{M}$. In cells incubated in the presence of $10 \mathrm{nM}$ DM, DOC (10 $\mu \mathrm{M})$ significantly inhibited ACE production compared with $10 \mathrm{nM}$ DM alone, suggesting that DOC is a partial agonist/partial antagonist in this enzyme system. Protein content of cells or medium was unchanged by steroids at all doses used.

In vivo, adrenalectomized rats showed lower pulmonary ACE compared with intact controls, and when injected with DM $(40 \mu \mathrm{g} / \mathrm{d}$ for $4 \mathrm{~d})$ showed a significant (twofold, $P<0.002$ ) increase in lung ACE over oil-injected, adrenalectomized controls; serum ACE did not change. Injection with DOC $(40 \mu \mathrm{g} / \mathrm{d})$ or aldosterone $(10 \mu \mathrm{g} / \mathrm{d}) \mathrm{had}$ no effect on lung or serum ACE. Over a range $(0.6$ to $2,000 \mu \mathrm{g})$ of concentrations of DM administered daily for $7 \mathrm{~d}$, the dose-response curve of DM for induction of pulmonary ACE mirrored that for thymolysis; for both, half-maximal effects were seen at $\sim 6 \mu \mathrm{g} \mathrm{DM} / \mathrm{d}$, and plateau levels at $60 \mu \mathrm{g} / \mathrm{d}$.
\end{abstract}

Received for publication 23 November 1981 and in revised form 18 May 1982.
We conclude that glucocorticoids are potent inducers of ACE activity in endothelial cells in culture and in rat lung in vivo, and that the action of aldosterone and DOC reflects occupancy of glucocorticoid receptors. This effect may be of (patho)physiological relevance in regulating levels of ACE in local vascular beds, and thereby modulating local levels of the vasoactive peptides angiotensin II and bradykinin.

\section{INTRODUCTION}

The production of angiotensin II (AII) ${ }^{1}$ from renin substrate is regulated by two enzymes: renin (EC 3.4.99.19) and angiotensin converting enzyme (ACE, peptidyldipeptide hydrolase, EC 3.4.15.1). The factors controlling release of renin have been intensively studied (1), but the regulation of ACE activity has been largely ignored.

ACE is localized to the luminal surface of vascular endothelial cells (2) and also occurs at other sites in tissues such as kidney (3), brain (4), and small intestine (5). Techniques for harvesting and culture of endothelial cells have been described (6), and the cultured cells have been shown to produce ACE in vitro (7). We therefore chose cultured endothelial cells as a convenient system to investigate the regulation of ACE production.

Previously, glucocorticoids have been shown to induce ACE production in rabbit alveolar macrophages in culture (8). There are, however, no published re-

\footnotetext{
${ }^{1}$ Abbreviations used in this paper: AI, AII, angiotensin I and II; ACE, angiotensin converting enzyme; Aldo, aldosterone; ANOVA, analysis of variance; DM, dexamethasone; DOC, deoxycorticosterone hemisuccinate; HL, histidyl-leucine; $\mathrm{LDH}$, lactate dehydrogenase.
} 
ports of steroid modulation of ACE in vascular endothelium, one possible mechanism whereby steroids might influence vascular tone. This is of interest since the hypertension of Cushing's syndrome in man has been reported to be dependent on AII (9), as has experimental hypertension due to glucocorticoid administration (10). The present demonstration, that endothelial ACE is induced by glucocorticoids both in vivo and in vitro, suggests a possible role in clinical and experimental hypertension associated with glucocorticoid excess.

\section{METHODS}

Bovine endothelial cell cultures. Endothelial cells were collected from fresh bovine aortae using collagenase digestion (11) and cultured in RPMI 1640 medium (Flow Laboratories, Stanmore, N.S.W., Australia) containing $30 \%$ fetal calf serum, amphotericin B $(1.25 \mu \mathrm{g} / \mathrm{ml})$, gentamycin $(80$ $\mu \mathrm{g} / \mathrm{ml}$ ), $2 \mathrm{mM}$ additional glutamine, and buffered with 15 $\mathrm{mM}$ HEPES to $\mathrm{pH}$ 7.5. Before the experiments described below, the cells were harvested with $0.025 \%$ trypsin- $0.02 \%$ EDTA, subcultured into $25-\mathrm{cm}^{2}$ flasks and grown to confluence.

Production of converting enzyme in vitro. Because fetal calf serum was found to contain high concentrations of ACE, it was necessary to culture the cells in serum-free medium. After the medium was removed from confluent subcultures of endothelial cells, and cells were washed twice with phosphate-buffered saline and once with RPMI medium free of fetal calf serum. $5 \mathrm{ml}$ of serum-free medium was added to each flask.

Steroids. Stock solutions of dexamethasone (DM, Sigma Chemical Co., St. Louis, Mo., lot no. 49C0474), deoxycorticosterone hemisuccinate (DOC, Steraloids, Inc., Pawling, NY, batch no. 7413), and aldosterone (Aldo; Sigma Chemical Co., lot no. 28C-0079) were freshly prepared in RPMI medium and volumes of $10-100 \mu \mathrm{l}$ added to the cultures to achieve the desired concentrations. Cultures were maintained at $37^{\circ} \mathrm{C}$ for $2 \mathrm{~d}$ in room air, and samples of cells and medium were collected from duplicate flasks. The medium was centrifuged at $1,700 \mathrm{~g}$ for $10 \mathrm{~min}$, and the supernatant stored at $-20^{\circ} \mathrm{C}$ for subsequent $\mathrm{ACE}$ assay; the cell pellet was combined with the cells from the culture flask, lysed in $2 \mathrm{ml}$ of distilled water, and stored at $-20^{\circ} \mathrm{C}$.

ACE assay. Samples of medium and cells were dialyzed at $4^{\circ} \mathrm{C}$ against distilled water for $24 \mathrm{~h}$ and then for $24 \mathrm{~h}$ against $300 \mathrm{mM} \mathrm{NaCl}, 50 \mathrm{mM}$ sodium phosphate buffer, $\mathrm{pH}$ 8.3 , to reduce the blank fluorescence derived from the medium. Cell suspensions were sonicated before dialysis. In both dialyzed media and cell sonicates, ACE was determined by a fluorometric procedure (12) using the substrate hippuryl-histidyl-leucine (Vega-Fox Biochemicals Div., Newbery Energy Corp., Tucson, AZ) under the assay conditions described by Cushman and Cheung (13), except that the incubation was prolonged to $2 \mathrm{~h}$ in order to increase the sensitivity of the assay. The generation of histidyl-leucine was linear with both time (15-120 min) and protein concentration of the sample (0.5-3 $\mu \mathrm{g}$ protein). Recovery of added histidyl-leucine $(10 \mathrm{nmol})$ was $98.4 \pm 2.4 \%$, (SD, $n$ $=10$ ). Protein content of cells and medium was measured by a modified Lowry method (14).

Characterization of the enzyme. The identity of the cleavage product after the ACE assay was checked by thin- layer chromatography on silica gel using n-butanol/acetic acid/water (18:2:5) as solvent. The spots were identified using ninhydrin and Pauly's reagent (15).

To assess the effect of $\mathrm{Cl}^{-}$on the activity of the enzyme, samples were dialyzed against $\mathrm{Cl}^{-}$-free, $50 \mathrm{mM}$ sodium phosphate buffer, $\mathrm{pH} 8.3$, and the incubation mixtures made up with a range of $\mathrm{NaCl}$ concentrations from 0 to $400 \mathrm{mM}$. The effect of the inhibitors $\mathrm{Na}_{2}$ EDTA, SQ 20881, and SQ 14225 (E. R. Squibb \& Sons, New York) was assessed on the enzyme activity.

Action of actinomycin $D$ and cycloheximide on the effect of DM. In two experiments inhibitors of translation and transcription were used to evaluate the mechanism of action of DM on ACE production. Actinomycin D $(40 \mu \mathrm{M}$, lot 1151416, Boehringer Mannheim Biochemicals, Indianapolis, IN) or cycloheximide (1 $\mu \mathrm{M}$, lot 501284, Calbiochem-Behring Corp., American Hoechst Corp., San Diego, CA) were added to cell cultures with and without DM (100 nM), and ACE production measured after $2 \mathrm{~d}$ as described above.

Lactate dehydrogenase assay. In one experiment the distribution of ACE, protein, and lactate dehydrogenase (LDH) between cells and medium was measured in cultures at day 0 and day 2 with and without DM $(100 \mathrm{nM})$ in order to assess the contribution of cell lysis to medium ACE. LDH assays (16) were performed on fresh, unfrozen samples of cells and medium before dialysis for ACE assay. In sonicated cells, incubated at $37^{\circ} \mathrm{C}$, no loss of LDH activity occurred over $24 \mathrm{~h}$.

Effect of steroids on lung and serum ACE in vivo. Female Sprague Dawley rats, bilaterally adrenalectomized 5 $\mathrm{d}$ previously, were injected daily for $4 \mathrm{~d}$ with either subcutaneous DM $(40 \mu \mathrm{g} / \mathrm{d})$, DOC $(40 \mu \mathrm{g} / \mathrm{d})$, Aldo $(10 \mu \mathrm{g} / \mathrm{d})$, or vehicle (peanut oil, $0.1 \mathrm{ml})$. The animals $(n=10$ per group) were killed by decapitation, serum collected for ACE assay, and the lungs homogenized in $9 \mathrm{vol}$ of $0.3 \mathrm{M} \mathrm{NaCl}$, $0.1 \mathrm{M}$ potassium phosphate buffer, $\mathrm{pH}$ 8.3. Homogenates were centrifuged at $1,000 \mathrm{~g}$ for $10 \mathrm{~min}$, the supernatant diluted 20 -fold in the phosphate buffer, and $10 \mu \mathrm{l}$ used for $\mathrm{ACE}$ assay.

In a dose-response study, female Sprague Dawley rats were adrenalectomized or sham-adrenalectomised, housed at a different institution (Medical Research Centre, Prince Henry's Hospital) and injected daily with DM $(0.6-2,000$ $\mu \mathrm{g} / \mathrm{d}$ ) in oil from the first to the seventh days inclusive postadrenalectomy. Six animals were used per group (sham adrenalectomised, adrenalectomised, and eight doses of DM).

Statistical analysis. The significance of changes in ACE and protein with steroid treatment was assessed by one-way analysis of variance (ANOVA) (17). Where treatment effects were significant by ANOVA, comparison of individual treatments with the control was by the least significant difference test using the error mean square obtained by ANOVA (17).

\section{RESULTS}

Characteristics of the enzyme. The enzyme activity produced by the cells in culture closely resembled classical ACE in several respects. It was inhibited 93 and $97 \%$ by EDTA $(1 \mathrm{mM}, 10 \mathrm{mM}), 78$ and $99 \%$ by SQ $20881(1 \mu \mathrm{M}, 25 \mu \mathrm{M})$, and 96 and $99 \%$ by SQ 14225 (1 $\mu \mathrm{M}$ and $25 \mu \mathrm{M})$. Thin-layer chromotography of the incubation mixture revealed the appearance of histidyl-leucine (HL) but neither histidine or leucine. The 

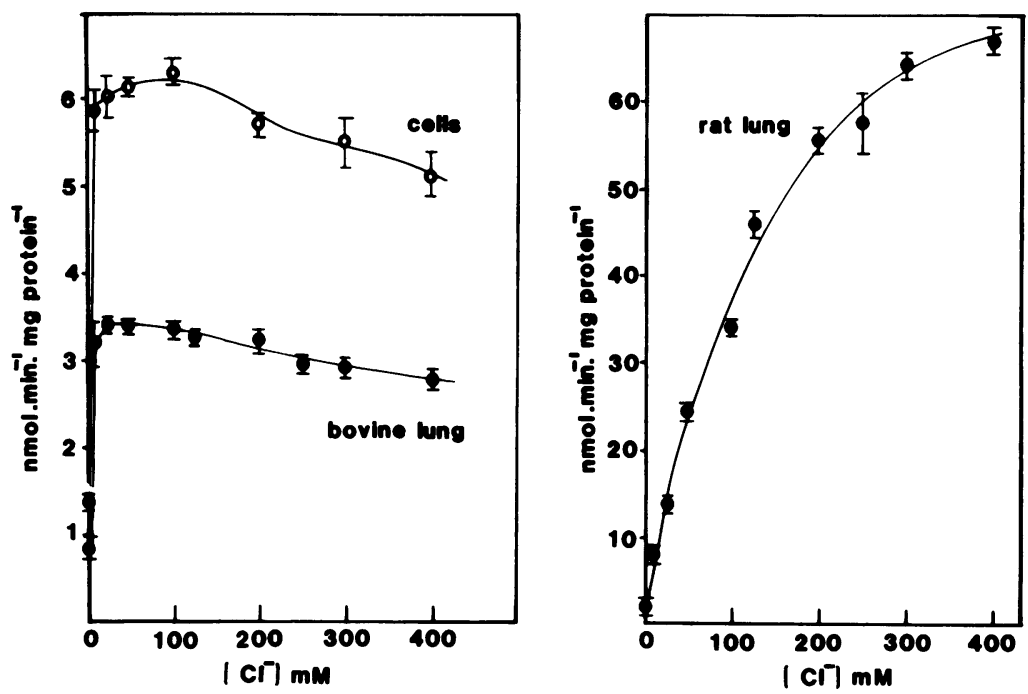

FIGURE $1 \mathrm{Cl}^{-}$activation of ACE derived from bovine endothelial cells in culture (cells), fresh bovine lung, or fresh rat lung.

release of HL was inhibited by EDTA or SQ 20881 . These results indicate the action of a dipeptidylcarboxypeptidase sensitive to EDTA and SQ 20881.

In the absence of $\mathrm{Cl}^{-}$the enzyme has only $\sim 20 \%$ of maximal activity. It was markedly activated by low concentrations of $\mathrm{Cl}^{-}$with a half maximal effect at $<2 \mathrm{mM}$ (Fig. 1). The profile of the $\mathrm{Cl}^{-}$activation curve of ACE from cultured endothelial cells closely resembled that obtained using microsomes from fresh bovine lung (Fig. 1) but was different from that observed for rat lung where the half maximal $\mathrm{Cl}^{-}$concentration was $\sim 100 \mathrm{mM}$.

Evidence for net production of $\mathrm{ACE}$ in vitro and its inhibition by cycloheximide in this system has been published (7).

Production of ACE during culture. Cell cultures in serum-free medium showed a net increase of total ACE content (cells and medium) from 104 \pm 12 (SEM, $n=16) \mathrm{pmol} \mathrm{HL} / \mathrm{min}$ per flask $\left(\sim 3-4 \times 10^{6}\right.$ cells $)$ to $247 \pm 35$ (SEM, $n=16$ ) after $2 \mathrm{~d}$. In terms of enzyme activity per milligram protein this represents an increase from $149 \pm 16$ to $286 \pm 45 \mathrm{pmol} / \mathrm{min}$ per $\mathrm{mg}$ protein. In the absence of steroids, after $2 \mathrm{~d}$, approximately equal activities of ACE were found in the medium $(130 \pm 19 \mathrm{pmol} / \mathrm{min}$ per flask, SEM, $n=16)$ and in the cells $(117 \pm 16)$. After $2 \mathrm{~d}$ of culture in serumfree medium, protein content in cells was $714 \pm 21 \mu \mathrm{g} /$ flask, and of medium was $176 \pm 7 \mu \mathrm{g} /$ flask, compared with values at day 0 of $646 \pm 32$ and $47 \pm 4 \mu \mathrm{g}$, respectively.

Effect of steroids on ACE production during culture. The effects of a range of concentrations of the steroids on ACE production by endothelial cells during
$2 \mathrm{~d}$ in serum-free culture is shown in Fig. 2. DM markedly increased ACE content of both cells and medium. The effects of DM on ACE content of cells and medium, and total ACE, were all highly significant (ANOVA, $\mathrm{F}_{5,8}=84.9, P=10^{-7} ; \mathrm{F}_{5,8}=8.8, P<0.004$, and $\mathrm{F}_{5,8}=54.8, P<10^{-5}$, respectively). The threshold effect $(P<0.05$ vs. control) occurred at $0.3 \mathrm{nM} \mathrm{DM}$ for cell ACE, $10 \mathrm{nM}$ for medium ACE, and $1 \mathrm{nM}$ for total ACE. A graded, almost linear, increase in ACE then occurred up to the highest dose of DM used (100 $\mathrm{nM})$. At $100 \mathrm{nM}$ DM, ACE in cells was six to seven times, and total ACE production four times that in controls without added steroid. In a different set of six separate experiments, DM (100 $\mathrm{nM})$ produced increases (mean $\pm \mathrm{SD}$ ) in $\mathrm{ACE}$ content of $664 \pm 29 \%$, $216 \pm 23 \%$, and $429 \pm 23 \%$ in cells, medium and total production, respectively.

In the presence of DM (100 $\mathrm{nM}), \mathrm{ACE}$ content of the cells was 2.9 ( $\mathrm{SD}=0.6, n=6$ ) times greater than the medium content; this contrasts with cultures without added steroid, where nearly equal values were found. Thus, DM not only increased total ACE content of the cultures, but also favoured storage of new ACE over release.

DOC and aldosterone produced highly significant increases in total ACE $\left(F_{5,8}=6.1, P<0.02\right.$, and $F_{5,8}$ $\left.=66.7, P<10^{-5}\right)$, but were both markedly less potent than DM (Fig. 2).

There was no effect of any of the three steroids on total protein content of either cells or medium (Table I). No differences in morphology were observed, between steroid-treated cells and control cultures, using a Leitz Wetzlar inverted light microscope. 


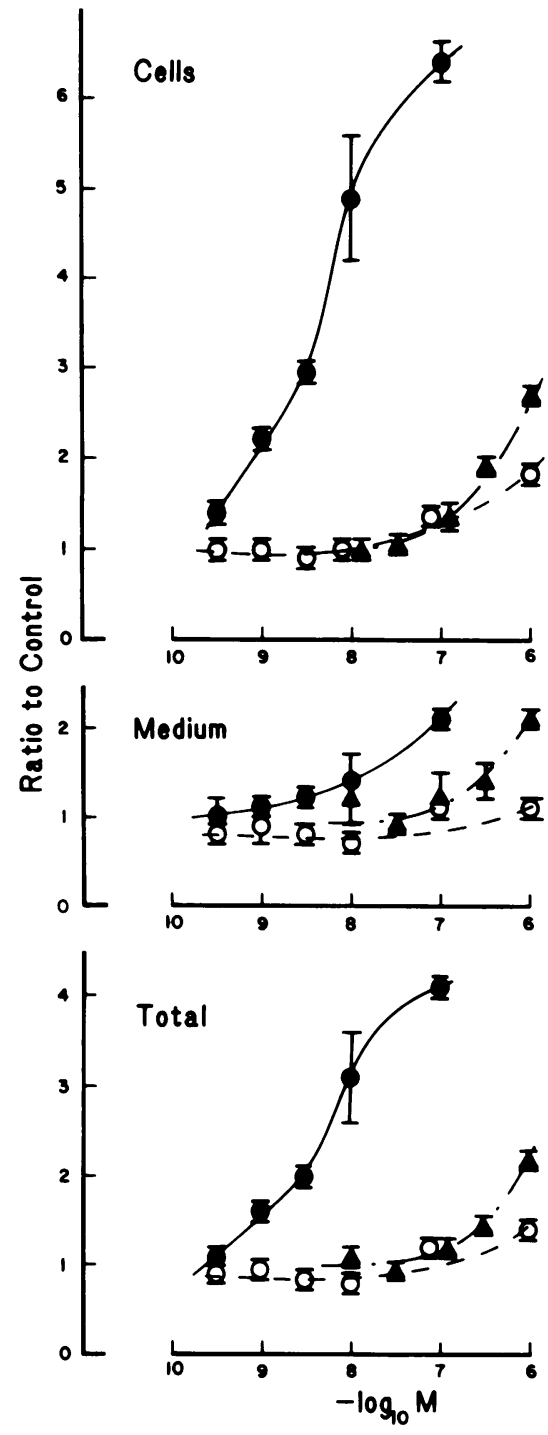

Figure 2 Dose-response curves for the effects of DM (๑), DOC $(O)$, and Aldo $(\Delta)$ on ACE specific activity $\mathrm{nmol} / \mathrm{min}$ per $\mathrm{mg}$ protein) in bovine endothelial cells, culture medium or both (total). ACE activity (mean and range, $n=2$ ) is expressed as a ratio of that in control cultures in each experiment.

Addition of any of the three steroids (0.1-10 $\mu \mathrm{M})$ to the ACE assay system had no effect on the rate of generation of histidyl-leucine $\left(\mathrm{F}_{3,6}=0.4, P>0.7\right)$.

Effects of culture and DM on cell and medium content of ACE, LDH, and total protein. In one study we have compared the effects of culture and steroid exposure on LDH and total protein, in addition to ACE, to evaluate the possible combination of cell lysis to medium ACE and the effects of steroid on the release of ACE. Table II shows values for ACE, LDH, and total protein in both cells and medium, before and after 2-d culture with or without DM (100 nM). Of particular interest is the proportion of total activity found in the medium in each case. In the absence of added steroid, ACE increased in both cells and medium; the percentage of total ACE in the medium

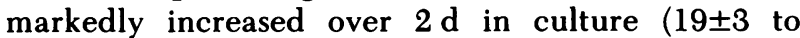
$42 \pm 2 \%$ ). This value is much higher than the extent of cell lysis as assessed by the increase in percentage of LDH or protein in the medium $(9.0,9.3 \%)$.

In the presence of DM (100 $\mathrm{nM})$, both medium and cell ACE were markedly increased after $2 \mathrm{~d}$, as shown previously. As opposed to the marked increase in medium ACE as a percentage of the total under steroidfree conditions, cells cultured with DM showed no change in medium to total ratio $(26 \pm 2,24 \pm 1 \%)$. In contrast, the medium proportions of both $\mathrm{LDH}$ and
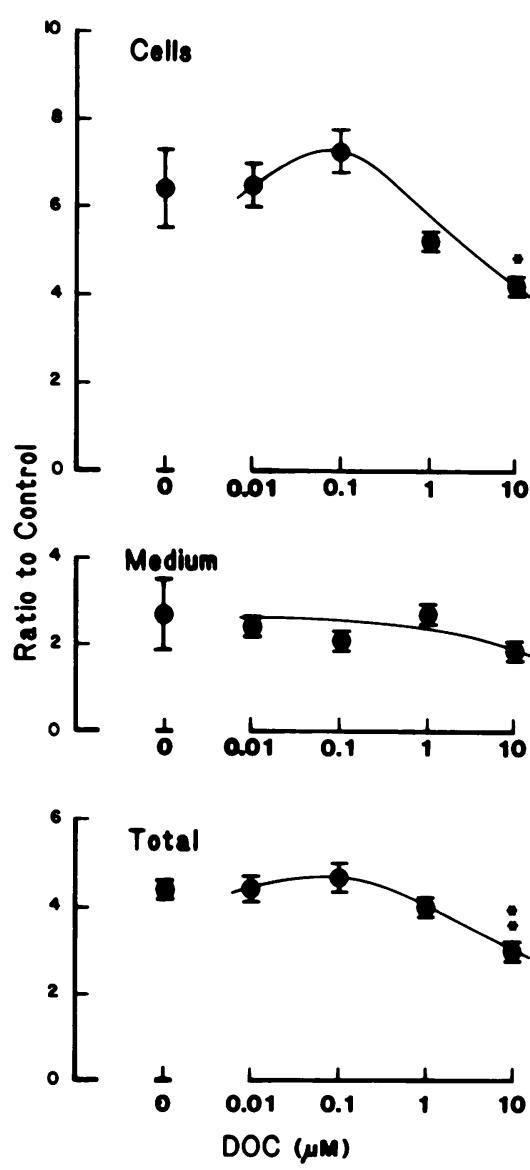

FIGURE 3 Effects of DOC on the ACE specific activity of endothelial cells, culture medium, or both (total) in the presence of $10 \mathrm{nM} \mathrm{DM}$ in all flasks. Results (mean and range, $n=2$ ) are expressed as a ratio of the activity in control cultures without added steroids. ${ }^{\circ} P<0.05 ;{ }^{\circ} P<0.01$, compared with DM alone. 
TABLE I

Effect of Steroids on Protein Content of Endothelial Cells in Culture

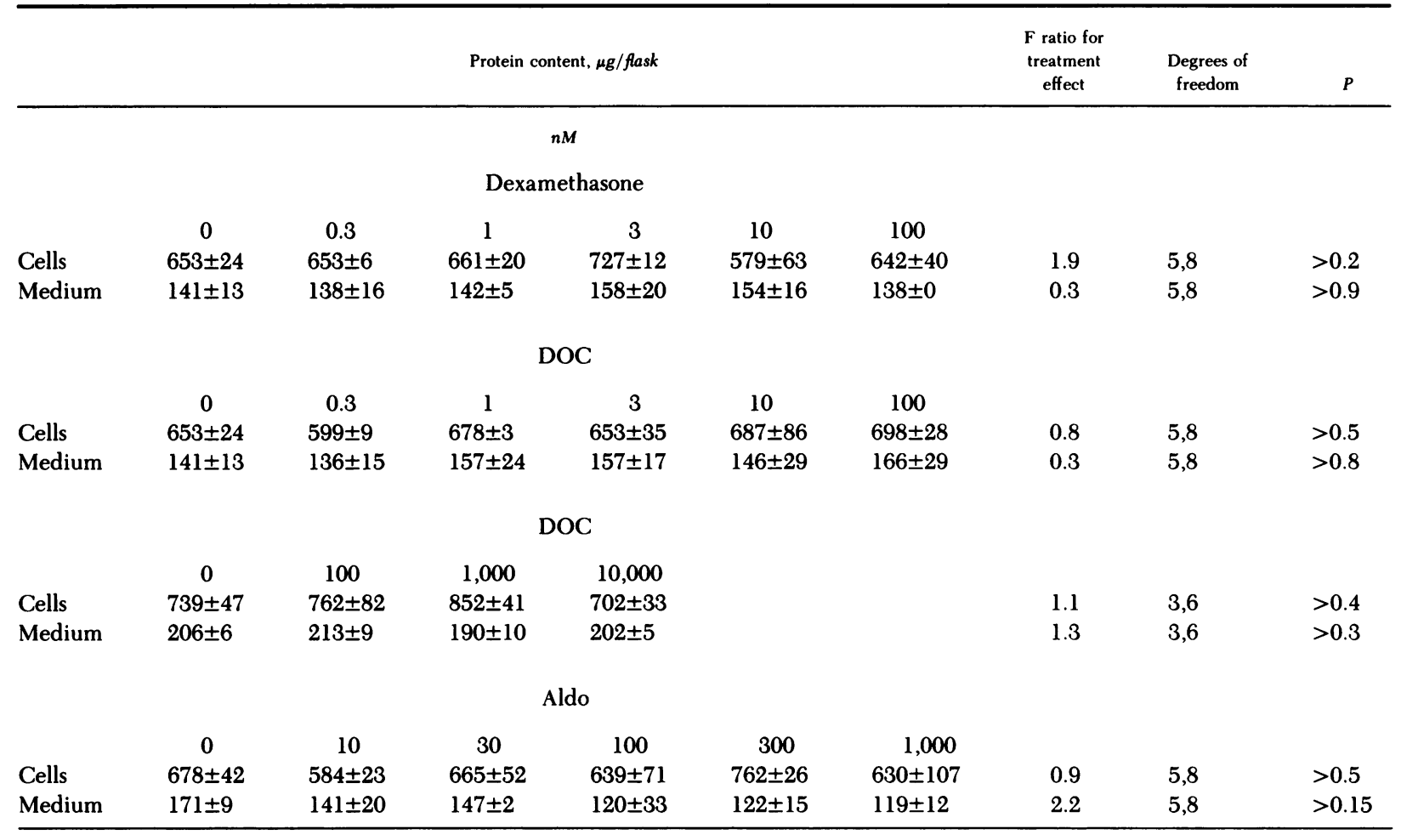

Values are mean $\pm \mathrm{SEM}, n=2-4$.

total protein were not affected by the presence or absence of DM.

Effects of inhibitors on DM stimulation of ACE production. In the experiment detailed in Table III, endothelial cell cultures showed an 8.4-fold increase in total ACE content (cells and medium) during culture for $2 \mathrm{~d}$. In the presence of DM $(100 \mathrm{nM}) \mathrm{ACE}$ production was further increased nearly sixfold. Both actinomycin $\mathrm{D}(40 \mu \mathrm{M})$ and cycloheximide $(1 \mu \mathrm{M})$ completely blocked the increases in total ACE content

TABLE II

Total Protein, LDH, and ACE in Cells and Medium

\begin{tabular}{|c|c|c|c|c|c|c|c|c|c|}
\hline & \multicolumn{3}{|c|}{ ACE } & \multicolumn{3}{|c|}{ LDH } & \multicolumn{3}{|c|}{ Protein } \\
\hline & Cells & Medium & $\begin{array}{l}\% \text { of total } \\
\text { in } \\
\text { medium }\end{array}$ & Cells & Medium & $\begin{array}{c}\% \\
\text { in } \\
\text { medium }\end{array}$ & Cells & Medium & $\begin{array}{c}\% \\
\text { in } \\
\text { medium }\end{array}$ \\
\hline & \multicolumn{2}{|c|}{$\mathrm{pmol} / \mathrm{min} /$ flask } & & \multicolumn{2}{|c|}{$m U /$ flask } & & \multicolumn{2}{|c|}{$\mu g /$ flask } & \\
\hline $\begin{array}{l}\text { Day } 0 \text { control, } \\
n=4 \\
\text { Day } 0 \text { DM } 100 \mathrm{nM}\end{array}$ & $179 \pm 6$ & $43 \pm 7$ & $19 \pm 3$ & $641 \pm 10$ & $39 \pm 2$ & $5.7 \pm 0.3$ & $335 \pm 9$ & $161 \pm 20$ & $32 \pm 3$ \\
\hline $\begin{array}{l}\quad n=4 \\
\text { Day } 2 \text { control, }\end{array}$ & $180 \pm 13$ & $62 \pm 7$ & $26 \pm 2$ & $651 \pm 30$ & $38 \pm 8$ & $5.5 \pm 1.2$ & $288 \pm 20$ & $176 \pm 15$ & $38 \pm 1$ \\
\hline $\begin{array}{l}n=4 \\
\text { Day } 2 \mathrm{DM}, 100 \mathrm{nM} \text {, }\end{array}$ & $413 \pm 22$ & $301 \pm 8$ & $42 \pm 2$ & $755 \pm 11$ & $133 \pm 10$ & $15 \pm 0.8$ & $351 \pm 22$ & $251 \pm 43$ & $41 \pm 6$ \\
\hline$n=4$ & $1909 \pm 117$ & $593 \pm 54$ & $24 \pm 1$ & $803 \pm 5$ & $131 \pm 15$ & $14 \pm 1.4$ & $342 \pm 28$ & $310 \pm 26$ & $48 \pm 1$ \\
\hline
\end{tabular}

Values are mean $\pm \mathrm{SEM}, n=4$. 
TABLE III

Effects of Inhibitors on DM Stimulation of ACE Production from Cultured Endothelial Cells

\begin{tabular}{|c|c|c|}
\hline \multirow[b]{2}{*}{ Incubation condition } & \multicolumn{2}{|c|}{$\begin{array}{l}\text { ACE content } \\
p m o l / m i n / f l a s k\end{array}$} \\
\hline & Basal & DM, $100 \mathrm{nM}$ \\
\hline Day 0 control & $\begin{array}{c}167 \pm 22^{\circ} \\
(3)\end{array}$ & - \\
\hline Day 2 control & $\begin{array}{c}1,433 \pm 193 \\
(4)\end{array}$ & $\begin{array}{c}8,232 \pm 491 \ddagger \\
(5)\end{array}$ \\
\hline $\begin{array}{l}\text { Actinomycin D, } \\
\quad 40 \mu \mathrm{M}\end{array}$ & $\begin{array}{c}170 \pm 33^{\circ} \\
(3)\end{array}$ & $\begin{array}{c}473 \pm 130 \S 11 \\
\text { (3) }\end{array}$ \\
\hline $\begin{array}{l}\text { Cycloheximide, } \\
\quad 1 \mu \mathrm{M}\end{array}$ & $\begin{array}{c}140 \pm 58 \ddagger \\
\text { (3) }\end{array}$ & $\begin{array}{c}370 \pm 104 \pi^{\prime \prime} \\
\text { (3) }\end{array}$ \\
\hline
\end{tabular}

Total ACE content of cells and medium combined before (day 0 control) or after 2 -d culture (day 2 control) with or without dexamethasone, actinomycin $D$, or cycloheximide. Values are mean \pm SEM with number of replicates in brackets.

- $P<0.005$, compared with day 2 control.

$\ddagger P<0.001$, compared with day 2 control.

$\S P<0.05$, compared with day 2 control

" $P<0.001$, compared with dexamethasone alone.

I $P<0.01$, compared with day 2 control.

of cultures incubated with or without DM; all values were below the day 2 control and approached the initial ACE activity on day 0 .

Cultures treated with the inhibitors for $2 \mathrm{~d}$ appeared morphologically normal under light microscopy.

Interaction of DOC and DM on ACE. In the experiment shown in Fig. 3, addition of DM (10 nM) produced an approximately sixfold increase in cell ACE specific activity and a two- to threefold increase in the medium ACE. Addition of DOC to the cultures containing $10 \mathrm{nM}$ DM lowered ACE specific activity in the cells $\left(F_{4,5}=5.3, P<0.05\right)$ and in the total ACE of cells and medium $\left(F_{4,5}=10.5, P=0.01\right)$.

Effects of steroids on ACE in vivo. Fig. 4 shows the effects of three steroids on lung and serum ACE of adrenalectomized rats. Treatment with DM was associated with a doubling of ACE activity in the lung $(\mathrm{t}=4.13, P<0.001)$ whereas the effects of DOC and aldosterone were not significantly different from control $(\mathrm{t}=1.64, P>0.1$ and $\mathrm{t}=1.03, P>0.3$, respectively). Serum ACE did not change with any of the steroid treatments $\left(F_{3,33}=1.7, P>0.17\right)$.

Dose-response curves for the effects of DM treatment on lung ACE and thymus weight in a separate group of animals are shown in Fig. 5. Adrenalectomized rats had lower lung ACE and higher thymus weight than sham-operated controls. Significant thy-

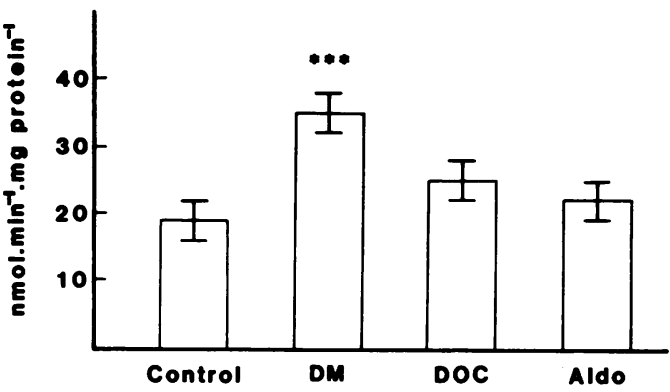

Figure 4 Effect of DM, $40 \mu \mathrm{g} / \mathrm{d}$, DOC, $40 \mu \mathrm{g} / \mathrm{d}$, Aldo, 10 $\mu \mathrm{g} / \mathrm{d}$, or vehicle (control) administered daily for $4 \mathrm{~d}$ on lung ACE activity of adrenalectomized rats. ${ }^{\cdots P}<0.001$, compared with control; $n=10$ per group. Values are mean \pm SEM.

molysis was observed with DM $2 \mu \mathrm{g} / \mathrm{d}$ and above. Lung ACE activity was significantly increased by DM $6 \mu \mathrm{g} / \mathrm{d}$ and above.

\section{DISCUSSION}

The current experiments show that bovine endothelial cells in culture produce an enzyme that closely resembles ACE in its susceptibility to inhibitors, cleavage of a dipeptide from a synthetic substrate, and marked $\mathrm{Cl}^{-}$activation. Although many groups have reported

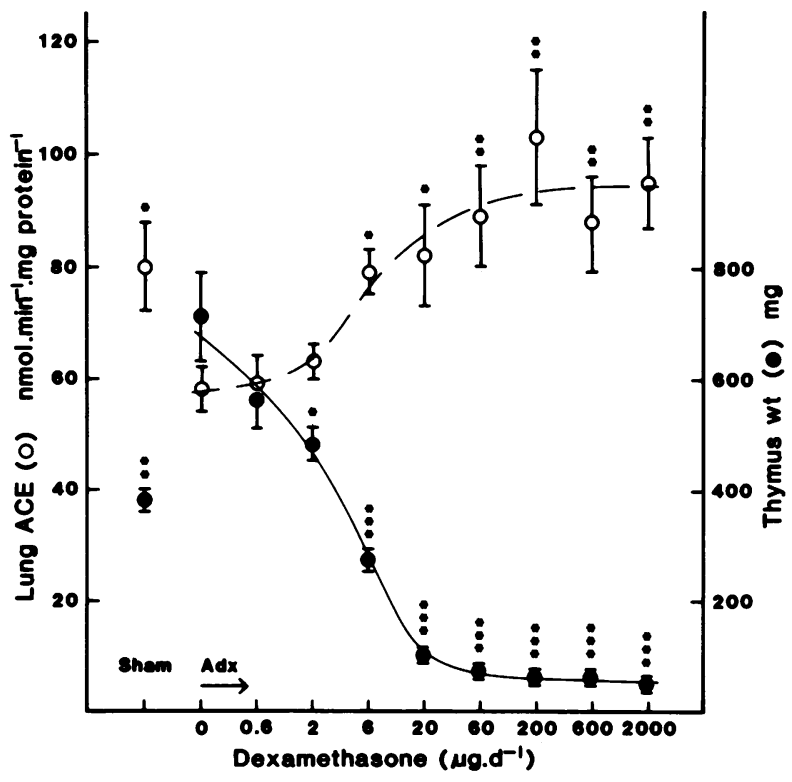

Figure 5 Effects of DM on thymus weight (0) and lung ACE activity (O) of adrenalectomized rats. Sham refers to sham-operated rats not given steroid. Significance values obtained by ANOVA are shown as: ${ }^{\circ} P<0.05$; ${ }^{\circ} P<0.01$; $\cdots P<0.001$, compared with adrenalectomized, oil-injected controls; $n=6$ per group. Values are mean \pm SEM. 
the presence of $\mathrm{ACE}$ activity in cultured endothelial cells, most of these observations are difficult to interpret due to high concentrations of ACE in fetal calf serum. This difficulty has often not been acknowledged but has recently been highlighted by others (18). There are, however, reports of production of ACE by endothelial cells cultured in medium free of ACE activity $(19,20)$.

In our study, DM produced a dramatic increase in ACE production in endothelial cells in culture. Glucocorticoids have been shown to increase the surface area and rate of protein synthesis by human umbilical endothelial cells in culture, but ACE activity was not assessed (21). Glucocorticoids have, however, been shown to induce ACE production by rabbit alveolar macrophages in culture (8), and in human monocytes (22) in culture. Although the physiological role of ACE in alveolar macrophages and circulating monocytes is currently unknown, the endothelial cell appears to be the major site of conversion of $\mathrm{AI}$ in vivo (23).

Contrasting the studies on macrophages and monocytes $(8,22)$, Johnson and Erdos (24) found no effect of cortisol $(15 \mu \mathrm{M})$ on ACE activity of cultured endothelial cells from human umbilical vein and pulmonary artery and vein. Both the species and anatomical site from which the cells were derived and the conditions of culture were different from this study. Their culture medium contained $20 \%$ fetal calf serum and $10 \%$ human serum, in contrast to our studies conducted in serum-free medium. It is possible that the endogenous levels of glucocorticoids in serum may stimulate control levels of ACE in cells, thus masking the glucocorticoid effect noted in our experiments. Alternatively, human endothelial cells in general, or umbilical and pulmonary vessel endothelial cells in particular, may be unresponsive to glucocorticoids.

In these experiments, adrenalectomized rats had lower lung ACE activity than controls; this was restored by low doses of DM, but not DOC or Aldo. These data suggest that induction of ACE occurs with physiological concentrations of glucocorticoids, and may thus be an important regulator of $\mathrm{ACE}$ in the intact animal.

That the induction of ACE in both bovine endothelial cells in vitro and rat lung in vivo is a glucocorticoidspecific effect is strongly suggested by several lines of direct evidence. In vitro, elevation of cell content of ACE occurs at a very low threshold concentration of $\mathrm{DM}(0.3 \mathrm{nM})$, and ACE levels rise progressively thereafter. In vivo, the fall in pulmonary ACE postadrenalectomy mirrors the rise in thymus weight; with progressively increasing doses of DM there are similarly parallel, opposite changes in thymus weight and pulmonary ACE. Finally, the glucocorticoid induction of
$\mathrm{ACE}$ is actinomycin $\mathrm{D}$ and cycloheximide inhibitable, evidence suggesting a classical action via DNA-dependent, RNA-mediated protein synthesis (25).

Thus, both in vivo and in vitro, ACE appears to be a system that is modulated by a classical glucocorticoid and not mineralocorticoid mechanisms. DOC $(40 \mu \mathrm{g})$ and Aldo $(10 \mu \mathrm{g})$ are near-maximal doses of steroid in terms of urinary electrolyte activity (26); their failure to elevate pulmonary ACE in lungs of adrenalectomized rats is, therefore, strong presumptive evidence against a specific mineralocorticoid effect on ACE in vivo; the high levels of DOC or Aldo required for in vitro induction are similarly consistent with an effect of these steroids by other than mineralocorticoid-specific mechanisms.

That Aldo and DOC at high concentrations can mimic, at least in part, the effect of DM of ACE is consistent with their modest affinity for glucocorticoid receptors and their partial or full glucocorticoid agonist activity upon occupying glucocorticoid receptors (27-29).

During culture of the cells in serum-free medium, the fraction of total ACE released into the medium increases disproportionately more than the fraction of either total protein or LDH. This suggests that ACE is selectively released into the medium rather than merely accumulating due to cell lysis. This process is consistent with the known localization of ACE as an ectoenzyme on the cell surface (23). DM had an interesting action in inhibiting this release process: in the presence of DM, marked increases in cell-ACE and a lesser increase in medium-ACE occurred, but the proportion of total ACE appearing in the medium was much less than in culture without steroid $(P<0.0001)$. No such effect occurred with either LDH or total protein, suggesting that this effect is specific for ACE. This phenomenon would explain why the magnitude of the effect of steroids on medium ACE was less and the dose-response curve shifted to the right compared with the effect on cell-ACE. A dual effect of glucocorticoids in increasing ACE synthesis and reducing its release would also explain why lung, but not serum $\mathrm{ACE}$, increased with DM in the in vivo experiments.

Although the mineralocorticoid hormones are commonly considered to be the predominant corticosteroids in terms of fluid and electrolyte homeostasis, a considerable number of functions related to salt and water handling have remained within the glucocorticoid domain. Examples of such effects are the glucocorticoid, but not mineralocorticoid, induction of $\mathrm{Na}^{+} /$ $\mathrm{K}^{+}$ATPase (30); the glucocorticoid dependence of renin substrate (31); and, from the data presented in this study, the specific glucocorticoid dependence of ACE. 
It has previously been assumed that peripheral ACE was not an important regulatory step in the control of AII production, based mainly on studies of the conversion of circulating AI across the lung (32). However, there is now evidence that AII may be formed locally in tissues such as kidney (33), brain (34), adrenal (35), and possibly vascular wall (36). Because ACE occurs in all of these sites $(2-4,23)$, it is probable that tissue levels of the enzyme could exert a regulatory role in the local production of AII.

In addition to its role in the conversion of AI to AII, $A C E$ is one of the enzyme systems concerned in the inactivation of bradykinin (23), a potent vasodilator. Steroid induction of ACE and consequent increased inactivation of bradykinin might contribute to the antiinflammatory effects of glucocorticoids and their reduction of vascular permeability. In terms of vascular tone, glucocorticoid-induced alterations in ACE levels might, thus, be expected to have a twofold effect: that of reciprocal changes in levels of the vasoconstrictor AII, and of the vasodilator bradykinin.

\section{ACKNOWLEDGMENTS}

This work was supported by grants from the Life Insurance Medical Research Fund of Australia and the National Heart Foundation of Australia.

\section{REFERENCES}

1. Davis, J. O., and R. H. Freeman. 1976. Mechanisms regulating renin release. Physiol. Rev. 56: 1-51.

2. Caldwell, P. R., B. C. Seegal, K. C. Hsu, M. Das, and R. L. Soffer. 1976. Angiotensin-converting enzyme: vascular endothelial localization. Science (Wash., DC). 191: 1050-1051.

3. Oshima, G., A. Gecse, and E. G. Erdos. 1974. Angiotensin I-converting enzyme of the kidney cortex. Biochim. Biophys. Acta. 350: 26-37.

4. Yang, H. Y. T., and N. H. Neff. 1972. Distribution and properties of angiotensin converting enzyme of rat brain. J. Neurochem. 19: 2443-2450.

5. Ward, P. E., M. A. Sheridan, K. J. Hammon, and E. G. Erdos. 1980. Angiotensin I converting enzyme (kininase II) of the brush border of human and swine intestine. Biochem. Pharmacol. 29: 1525-1529.

6. Gimbrone, M. A., Jr. 1976. Culture of vascular endothelium. Prog. Hemostasis Thromb. 3: 1-28.

7. Mendelsohn, F. A. O., and C. Kachel. 1981. Production of angiotensin converting enzyme by cultured bovine endothelial cells. Clin. Exp. Pharmacol. Physiol. 61: S277-S280.

8. Friedland, J., C. Setton, and E. Siverstein. 1977. Angiotensin converting enzyme: induction by steroids in rabbit alveolar microphages in culture. Science (Wash., DC). 197: 64-65.

9. Dalakos, T. G., A. N. Elias, G. H. Anderson, D. H. P. Streeton, and E. T. Schroeder. 1978. Evidence for an angiotensinogenic mechanism of the hypertension of Cushing's syndrome. J. Clin. Endocrinol. Metab. 46: 114-118.
10. Krakoff, L. R., R. Selvadurai, and E. Sutter. 1975. Effects of methylprednisolone upon arterial pressure and the renin angiotensin system in the rat. Am. J. Physiol. 228: 613-617.

11. Booyse, F. M., B. J. Sedlak, and M. E. Rafelson. 1975. Culture of arterial endothelial cells. Characterization and growth of bovine aortic cells. Thromb. Haemostasis. 34: 825-839.

12. Piquilloud, Y., A. Reinharz, and M. Roth. 1970. Studies on the angiotensin converting enzyme with different substrates. Biochim. Biophys. Acta. 206: 136-142.

13. Cushman, D. W., and H. S. Cheung. 1971. Spectrophotometric assay and properties of the angiotensin-converting enzyme of rabbit lung. Biochem. Pharmacol. 20: 1637-1648.

14. Hartree, E. F. 1972. Determination of protein: a modification of the Lowry method that gives a linear photometric response. Anal. Biochem. 48: 422-427.

15. Leggett Bailey, J. 1967. Techniques In Protein Chemistry, 2nd edition. Elsevier Publishing Company, Amsterdam. 23.

16. Bergmeyer, H. U., and E. Bernt. 1974. Lactate dehydrogenase. UV-assay with pyruvate and NADH. In Methods of Enzymatic Analysis. H. U. Bergmeyer, editor. 2nd English edition. Academic Press, Inc., New York. 2: 574-579.

17. Armitage, P. 1971. Statistical Methods in Medical Research. First edition. Blackwell Scientific Publications, Oxford, England. 217.

18. Ryan, U. S., and J. W. Ryan. 1980. Angiotensin converting enzyme. II. Pulmonary endothelial cells in culture. Environ. Health Perspect. 35: 171-180.

19. Ryan, U. S., E. Clements, D. L. Habliston, and J. W. Ryan. 1978. Isolation and culture of pulmonary artery endothelial cells. Tissue Cell 10(Pt. 3): 535-554.

20. Hayes, L. W., C. A. Goguen, S. Ching, and L. L. Slakey. 1978. Angiotensin-converting enzyme: accumulation in medium from cultured endothelial cells. Biochem. Biophys. Res. Commun. 82: 1147-1153.

21. Maca, R. D., G. L. Fry, and J. C. Hoak. 1978. The effects of glucocorticoids on cultured human endothelial cells. Br. J. Haematol. 38: 501-509.

22. Friedland, J., C. Setton, and E. Silverstein. 1978. Induction of angiotensin converting enzyme in human monocytes in culture. Biochem. Biophys. Res. Commun. 83: 843-849.

23. Erdos, E. G. 1977. The angiotensin I converting enzyme Fed. Proc. 36: 1760-1765.

24. Johnson, A. R., and E. G. Erdos. 1979. Angiotensin I converting enzyme (kininase II) in human endothelial cells in culture. Adv. Exp. Med. Biol. 120B: 287-295.

25. Baxter, J. D., and J. W. Funder. 1979. Hormone receptors. N. Eng. J. Med. 301: 1149-1161.

26. Sennett, J. A., R. D. Brown, D. P. Island, L. R. Yarbro, J. T. Watson, P. E. Slaton, J. W. Hollifield, and G. W. Liddle. 1975. Evidence for a new mineralocorticoid in patients with low-renin essential hypertension. Circ. Res. 36(Suppl. I): 1-9.

27. Tomkins, G. M. 1970. Relation of steroid structure to enzyme induction in hepatoma tissue culture cells. $J$. Mol. Biol. 52: 57-74.

28. Vale, W., J. Rivier, R. Guillemin, and C. Rivier. 1979. Effects of purified CRF and other substances on the secretion of ACTH and $\beta$-endorphin-like immunoactivities of cultured anterior or neurointermediate pituitary cells. In Central Nervous System Effects of Hypothalamic 
Hormones and Other Peptides. R. Collu, A. Barbeau, J. Ducharme, and J. G. Rochefort, editors. Raven Press, New York. 163-176.

29. Rousseau, G. G., and J. P. Schmidt. 1979. Structure-activity relationships for glucocorticoids: determination of receptor binding and biological activity. J. Steroid Biochem. 8: 911-919.

30. Charney, A. N., P. Silva, A. Besserab, and F. H. Epstein. 1974. Separate effects of aldosterone, DOCA and methylprednisolone on renal Na-K-ATPase. Am. J. Physiol. 227: 345-350.

31. Reid, I. A., W. H. T. K. Otsuka, T. A. Assaykeen, and W. F. Ganong. 1973. Studies concerning the regulation and importance of plasma angiotensinogen and importance of plasma angiotensinogen concentration in the dog. Endocrinology. 93: 107-114.
32. Vane, J. R. 1974. The fate of angiotensin I. In Angiotensin, Handbook of Experimental Pharmacology. I. H. Page and F. M. Bumpus, editors. Springer-Verlag, Berlin. 27: $17-40$.

33. Mendelsohn, F. A. O. 1979. Evidence for the local occurrence of angiotensin II in rat kidney and its modulation by dietary sodium intake and converting enzyme blockade. Clin. Sci. (Lond.). 57: 173-179.

34. Ganten, D., and G. Speck. 1978. The brain renin-angiotensin system: a model for the synthesis of peptides in the brain. Biochem. Pharmacol. 27: 2379-2389.

35. Aguilera, G., A. Schirar, A. Baukal, and K. J. Catt. 1981. Circulating angiotensin II and adrenal receptors after nephrectomy. Nature (Lond.). 289: 507-509.

36. Swales, J. D. 1979. Arterial wall or plasma renin in hypertension. Clin. Sci. (Lond.). 56: 293-298. 